\title{
Fungal Flora Associated with Indian and Foreign Coins and Their Potential Health Risks
}

\author{
Drishti Navlani*, Aditi Maheshwari, Vidhatri Thakkar, Roheel Taunk, \\ Naitik Chaudhary and Arun Arya \\ Department of Environmental Studies, Faculty of Science, The Maharaja Sayajirao \\ University of Baroda, Vadodara, India \\ *Corresponding Author: Drishti Navlani, Department of Environmental Studies, \\ Faculty of Science, The Maharaja Sayajirao University of Baroda, Vadodara, India.
}

DOI: 10.31080/ASMI.2020.03.0519
Received: January 30, 2020

Published: February 10, 2020

(C) All rights are reserved by Drishti Navlani., et al.

\section{Abstract}

Potential role of spread of pathogenic miroflora on coins and currency notes has been evaluated in different countries. Notes and currency coins may serve as universal vehicles for transmission of potentially pathogenic microorganisms among persons either directly, through hand to hand contact, or indirectly, through water and food. The Purpose of study was to do qualitative and quantitative analysis of microflora associated with Indian and foreign coins.

Results of the study revealed that bacteria were present in most of the coins, more than $40 \%$ coins showed presence of fungi like Aspergillus niger, Curvularia lunata, Chaetomium globosum, Fusarium roseum and Trichoderma viride. Fungi like Aspergillus niger and Fusarium roseum can cause bronchial diseases and may act as potential allergens and few of these are reported to cause skin problems. The Use of digital transaction will reduce such harmful transaction. Cleaning the coins with water or UV treatment may reduce the fungal load.

Total 100 coins were screened of which 20 were foreign coins. Isolation from these coins resulted into 20 cultures and 6 non sporulating mycelia. Oldest coins was 141 years and new coin was of 2015. Un-circulated Indian coin of 2003 was also tested.

Keywords: Currency Coins; Indian; Foreign; Aspergillus; Fusarium; Chaetomium; Penicillium

\section{Introduction}

Money is important for business. The coins and currency notes are used in market to purchase or sell the articles. Money in form of currency notes and coins is handled by persons of varying health and hygiene standards and also stored under varied environmental conditions. Consequently, chances of pathogens being present on money and persisting through multiple handling cannot be under estimated [1]. Money in form of coins is used since ancient times. The coins were made in Adil Shahi Dynasty in the $11-16^{\text {th }}$ century. The Rupee and other coins are usually round because they move from place to place in the earth which is also round, And it is prevented from disfiguring. The coins are reported to have speices of Aspergillus, Mucor of Rhizopus many of such microbes may be potential allergens. It has been established that E. coli and Salmonella enteritidis can survive up to eleven and nine days respectively on the surfaces of coins, thus making it possible for coins to transfer bacteria to human hands [2].
Coins are made up of metals like $\mathrm{Fe}$ and $\mathrm{Cr}, \mathrm{Ag}, \mathrm{Cu}, \mathrm{Ni}$ and $\mathrm{Zn}$. Experiments have shown that two fungi Aspergillus niger and Penicillium simplicissimum were able to mobilize $\mathrm{Cu}$ and $\mathrm{Sn}$ by $65 \%$ and $\mathrm{Al}, \mathrm{Ni}, \mathrm{Pb}$ and $\mathrm{Zn}$ by more than $95 \%$. It is known that the fungi like $A$. niger can produce organic acids like citric acid which can dissolve the metal or affect the shining of a new coin. Kuria., et al. [3] studied the presence of bacteria and fungi on coins. They found presence of fungi like Penicillium, Fusarium, Rhizopus and Alternaria spp. Since not much studies are conducted on coins we have in our purse. It was thought desirable to study the fungal organisms present in circulating and stored coins.

Money coins can be contaminated during production, storage and subsequent exchangers. Pollen grains and fungal spores may act as aeroallergens hence study was undertaken to access the occurrence of microflora on India and foreign coins and identify the fungal organism by pure culture method. Results are recorded in (Table 1 and 2). 


\begin{tabular}{|c|c|c|c|c|}
\hline Sr. No. & Coin Denomination & Country & Year & Occurrence of Fungi \\
\hline 1. & 10 cent & Canada & 1867 & Aspergillus niger van Tieghem \\
\hline 2. & 1 Euro & Europe & 1914 & $\begin{array}{l}\text { Aspergillus awamori Nakaz. } \\
\text { Chaetomium globosum Kunze. }\end{array}$ \\
\hline 3. & 1000 Lira & Turkey & 1919 & Chaetomium globosum Kunze. \\
\hline 4. & 50 Yen & Japan & 1919 & Rhizopus stolonifer (Ehrenb.) Vuill. \\
\hline 5. & 1 Yen & Japan & 1919 & Bacteria only No Fungus \\
\hline 6. & 10 pennig & Germany & 1950 & Aspergillus niger van Teighem \\
\hline 7. & 5 Peso & Mexico & 1976 & Alternaria alternata (Fr.) Keissl. \\
\hline 8. & 1 Peso & Mexico & 1976 & Alternaria alternata (Fr.) Keissl \\
\hline 9. & 5 Chhertum & Bhutan & 1979 & Bacteria \\
\hline 10. & 50 yen & Japan & 1979 & $\begin{array}{l}\text { Curvularia lunata Boedjn. } \\
\text { Chaetomium globosum Kunze. }\end{array}$ \\
\hline 11. & L. 500 & Italy & 1983 & Aspergillus niger van Tieghem \\
\hline 12. & 25 cent & Canada & 1985 & NILNo. Fungus \\
\hline 13. & 25 cent & “ & 1985 & Chaetomium globosum Kunze. \\
\hline 14. & 1 cent & “ & 1988 & Penicillium citrinum Thom \\
\hline 15. & 25 cent & “ & 1988 & Thielavia terricola (Gilman \& Abbott) Emmons \\
\hline 16. & United Arab emirates 1E10 & UAE & 1990 & Chaetomium globosum Kunze. \\
\hline 17. & 1 cent & Canada & 1993 & Aspergillus awamori Nakaz. \\
\hline 18. & 10 cent & “ & 1993 & Rhizopus stolonifer (Ehrenb.) Vuill. \\
\hline 19. & 5 cent & USA & 1998 & Aspergillus awamori Nakaz. \\
\hline 20. & 25 cent & USA & 2000 & Alternaria alternata (Fr.) Keissl. \\
\hline
\end{tabular}

Table 1: List of fungi isolated from Foreign coins during , 2017 -2018.

\begin{tabular}{|c|c|c|c|}
\hline Sr. No. & Coin Denomination & Year & Occurrence of Fungi \\
\hline 1. & East India Co. & 1842 & Chaetomium globosum Kunze \\
\hline 2. & One anna & 1928 & Penicillium citrinum Thom \\
\hline 3. & Quarter Anna & 1940 & Aspergillus niger van Tieghem \\
\hline 4. & One anna & 1913 & Rhizopus stolonifer (Ehrenb.) Vuill. \\
\hline 5. & One quarter anna & 1889 & Aspergillus niger van Teighem \\
\hline 6. & One quarter anna & 1917 & Thielavia terricola (Gilman \& Abbott) Emmons \\
\hline 7. & Five Paisa & 1974 & Rhizopus stolonifer (Ehrenb.) Vuill. \\
\hline 8. & Ten Paisa & 1986 & Alternaria alternata (Fr.) Keissl \\
\hline 9. & Twenty Paise & 1984 & Aspergillus niger van Tieghem \\
\hline 10. & Twenty Five Paise & 1986 & Aspergillus awamori Nakaz. \\
\hline 11 & One Rupee & 2015 & Aspergillus niger van Teighem \\
\hline 12. & Two rupee & 2009 & Rhizopus sp. \\
\hline 13. & Five rupee & 2010 & Chaetomium globosum Kunze. \\
\hline 14. & Five rupee & 2010 & Aspergillus awamori Nakaz. \\
\hline 15. & Two Rupee & 1990 & Aspergillus niger van Tieghem \\
\hline 16. & Two Rupees & 1998 & Aspergillus niger van Tieghem \\
\hline 17. & Five rupees & 2010 & Aspergillus niger van Tieghem \\
\hline 18. & Ten rupees & 2010 & Rhizopus stolonifer (Ehrenb.) Vuill. \\
\hline 19 & One rupee & 1986 & Rhizopus stolonifer (Ehrenb.) Vuill. \\
\hline 20 & Hundred Rs. & 2003 & Fusarium oxysporum Schltdl. \\
\hline
\end{tabular}

Table 2: List of fungi isolated from Indian coins during, 2017 -2018. 


\section{Materials and Methods}

Coins were collected from shopkeepers and coin collectors. During 2017 and 2018 total. 100 coins were screened by direct plating methods. Out of these 20 foreign and 80 Indian coins were studied. A medium supplemented with $5 \% \mathrm{NaCl}$ was also used. Fungi were isolated by direct plating method, dilution plate and direct plating method using PDA medium. Isolated fungi were photographed. The isolated fungi are listed in table 1 and 2.

\section{Results and Discussion}

Hundred coins, were screened for the presence of Fungal flora. These coins were made by different metals like $\mathrm{Ag}, \mathrm{Fe}, \mathrm{Ni}, \mathrm{Cr}$ and Zn etc.

In new coins minted after 1947 species of fungi like A. niger, Rhizopus stolonifer and Chaetomium globosum were detected in the month of June - July 2010 and A.niger, Penicillium citrinum and Rhizopus stolonifer during August, September 2010. Fungi present on foreign coins were Aspergillus awamori, A. niger, A. terreus, Alternaria alternata, Thielavia terricola, Penicillium citrinum, $P$. chrisogenum, Rhizopus stolonifer, Chaetomium globosum, Trichoderma viride, etc.

Arya., et al. [4] and Khandelwal [5] found that several Aspergillus spp. present in air of Baroda and Lucknow (India) may be potential allergens. Aspergillus and Penicillium may be considered as two most serious organisms. Some of the species of these fungi can survive up to 30 - 40 years [3,6]. Kuria., et al. [3] studied fungi associated with coins in Nairobi, Kenya. They found presence of fungi in 34 out of 40 coins. The significant isolates included Penicillium spp. A. niger Fusarium spp. Rhizopus and Alternaria spp. Yeast were present in 14 out of 40 coins. Enumeration of pathogens was found to be extremely difficult. It was found that certain species of fungi may act as allergens, dermatophytes and detrimental to eyes, lungs, urinogenitcal tracts etc. The coins transferred from shop keepers dealing with eatables or from temples may carry germs of diseases and it is, therefore, advisable to handle food material by some person and handling the money by others. Appearance, experiment and dip the coins into different solutions.

The metallic composition of pennies has been almost consistent throughout the years. Pennies have been made out of a mixture of copper and zinc and, at times, tin. With the exception of a steeland zinc-coated version in 1943, however, all pennies are coated in copper, which like other precious metals will tarnish when exposed to oxygen. To restore a penny's shinning appearance cleaning is required.

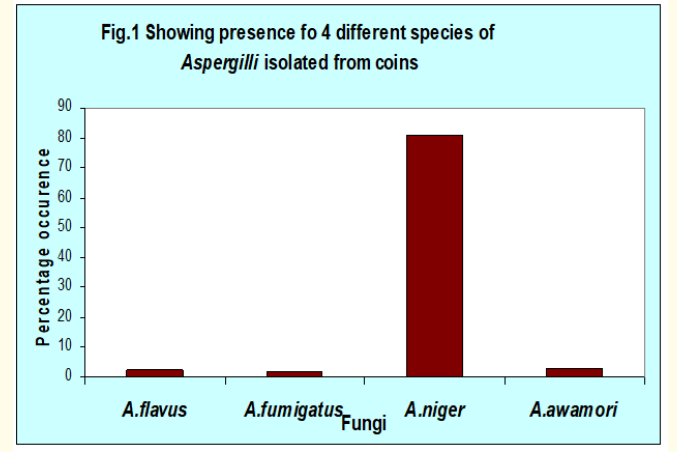

Figure 1: Showing presence of different species of Aspergilli isolated from coins

Presence of Aspergillus niger was more dominant.

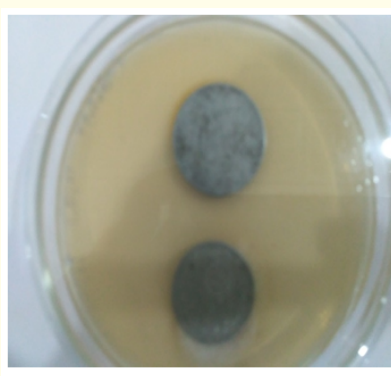

A
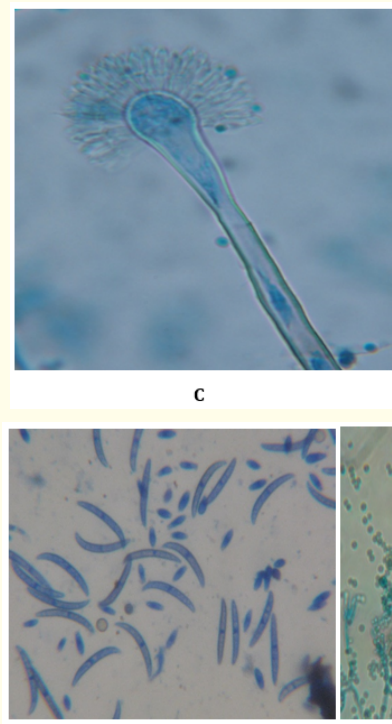

E

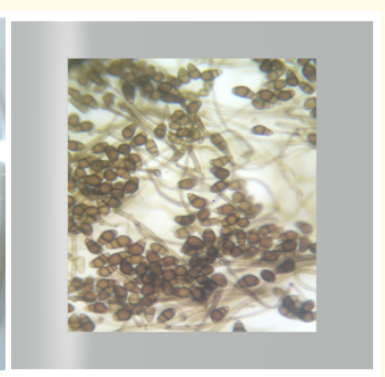

B
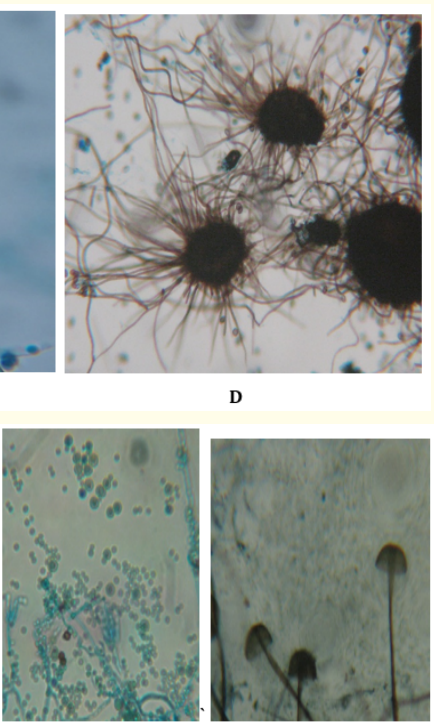

F

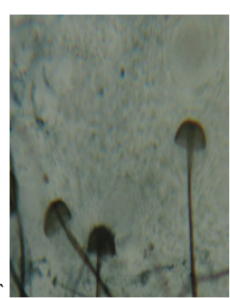

G
Figure 2: A. Isolation from Coins madeup of Copper B. Conidia of Curvularia Magnification 45X C. Aspergillus D. Chaetomium E. Fusarium F. Trichoderma G. Rhizopus 


\section{Conclusion}

Aspergilli are weak pathogens and potential carcinogens. These fungal agents may survive on coins having dust and pollens adhering into it. The fungus Aspergillus niger was most common agent present on it. Asexual state was more common.

\section{Acknowledgements}

Authors are thankful to UGC for financial assistance And to head Department of Environmental studies for providing lab facilities to.

\section{Bibliography}

1. Michaels B. "Handling money and serving ready to eat food". Journal of Food Science and Technology 2 (2002): 1-3.

2. Jiang X and Doyle MP. "Fate of Escherichia coli 0157:H7 and Salmonella enteritidis on money coins". Journal of Food Protection 62 (1999): 805-807.

3. Kuria JKN., et al. "Profile of bacteria and fungi on money coins". East African Medical Journal 86.4 (2009): 151-155.

4. Arya A., et al. 2001. "Indoor aeromicoflora of Baroda museum and deterioration of Egyptian Mummy". Current Science 81.7 (2001): 793-799.

5. Khandelwal A. In: Biodeterioration of cultural property (eds.) Agrawal O.P. and Dhavan S. Pub by Macmillen India Ltd. New Delhi (1991): 387-396.

6. Agrawal OP and Dhavan S. "Control of Biodeterioration in $\mathrm{Mu}-$ seum”. NRLC. Luknow (1985): 200.

\section{Assets from publication with us}

- Prompt Acknowledgement after receiving the article

- Thorough Double blinded peer review

- Rapid Publication

- Issue of Publication Certificate

- High visibility of your Published work

Website: https://www.actascientific.com/

Submit Article: https://www.actascientific.com/submission.php Email us: editor@actascientific.com

Contact us: +919182824667 